\title{
NOVEL MICROORGANISM FOR SELECTIVE SEPARATION OF COAL FROM ASH AND PYRITE
}

DOE Grant No. DE-FG22-93PC93215

Sixth Quarterly Technical Progress Report

(January 1, 1995 - March 31, 1995)

Submitted by

Professor Manoranjan Misra (PI)

Professor Ross W. Smith (Co-PI)

Ashok M. Raichur (Graduate Student)

Department of Chemical and Metallurgical Engineering

Mackay School of Mines

University of Nevada, Reno

Reno, NV 89557

\section{DISCLAIMER}

This report was prepared as an account of work sponsored by an agency of the United States Government. Neither the United States Government nor any agency thereof, nor any of their employees, makes any warranty, express or implied, or assumes any legal liability or responsibility for the accuracy, completeness, or usefulness of any information, apparatus, product, or process disclosed, or represents that its use would not infringe privately owned rights. Reference herein to any specific commercial product, process, or service by trade name, trademark, manufacturer, or otherwise does not necessarily constitute or imply its endorsement, recommendation, or favoring by the United States Government or any agency thereof. The views and opinions of authors expressed herein do not necessarily state or reflect those of the United States Government or any agency thereof. 


\section{DISCLAIMER}

Portions of this document may be illegible in electronic image products. Images are produced from the best available original document. 


\section{TABLE OF CONTENTS}

SUMMARY

1

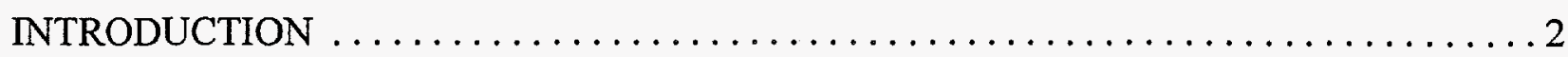

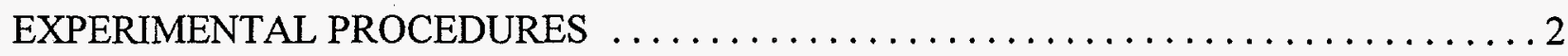

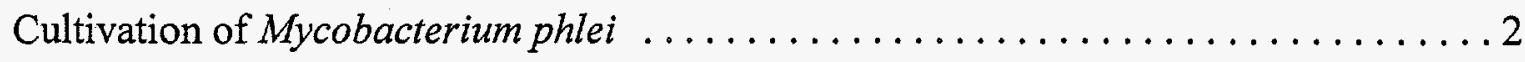

Sedimentation and Flocculation Experiments $\ldots \ldots \ldots \ldots \ldots \ldots \ldots \ldots \ldots \ldots \ldots$

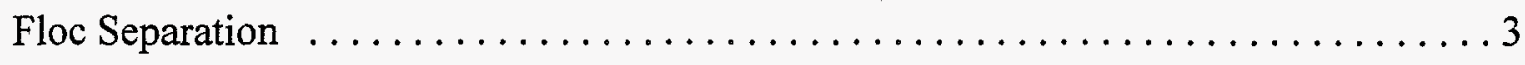

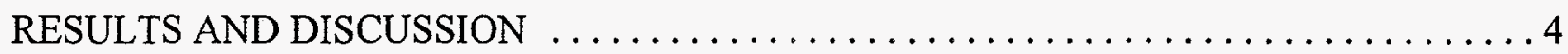

Sedimentation and Flocculation Experiments $\ldots \ldots \ldots \ldots \ldots \ldots \ldots \ldots \ldots$

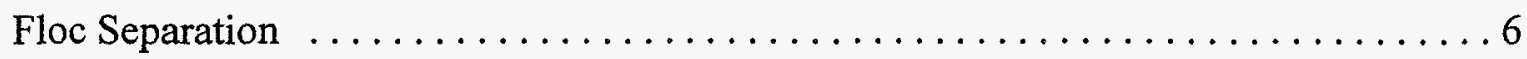

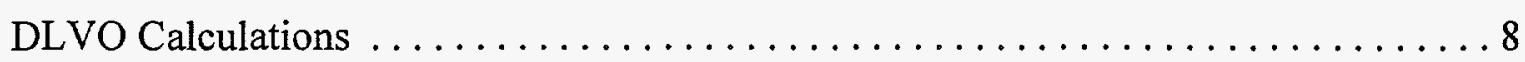

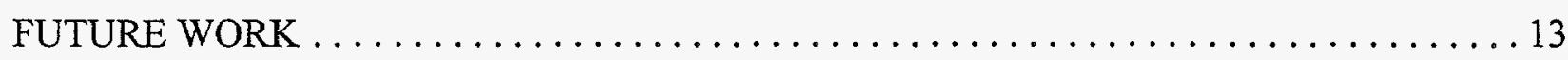

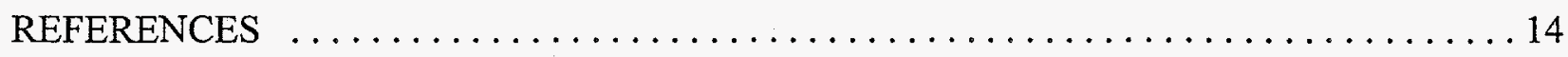




\section{SUMMARY}

This report summarizes the progress made during the sixth quarter of the research project entitled "A Novel Microorganism for Selective Separation of Coal from Ash and Pyrite", DOE Grant No. DE-FG22-93PC93215.

The objective of this research project is to study the effectiveness of a novel hydrophobic microorganism, Mycobacterium phlei (M. phlei), for the selective flocculation of coal from pyrite and ash forming minerals. During the reporting period, the flocculation efficiencies of Illinois No.6 and KY No.9 coal in the presence of whole and ruptured cells of $M$. phlei were studied. The effect of synthetic flocculants were also studied for comparison at selected $\mathrm{pH}$ values. Results showed that the whole cells of $M$. phlei can flocculate coal very effectively and rapidly for both the coal samples. However, with ruptured cells of $M$. phlei the flocculation efficiency is significantly less which can be attributed to the loss of extracellular surfactants during rupturing. Separation of flocs using column flotation was studied for both the coal samples in the acidic $\mathrm{pH}$ range. Results indicated that excellent rejection of pyritic sulfur and ash could be obtained with a high combustible recovery. DLVO calculations were performed for all the minerals used in this study to calculate the interaction energies in the presence of whole cells and ruptured cells of $M$. phlei. A minimum in interaction energy is observed between coal and whole cells of $M$. phlei at $\mathrm{pH} 4$ which is probably responsible

for the higher adhesion and flocculation efficiencies at that $\mathrm{pH}$. However, with ruptured cells the interaction energy increases thus decreasing the amount of $M$. phlei cells adhering to the surface. 


\section{INTRODUCTION}

The selective separation of pyrite and ash-forming minerals from coal can be accomplished by flotation, agglomeration and selective flocculation. The methods currently used for selective flocculation of coals include addition of natural or synthetic polymeric flocculants along with precise $\mathrm{pH}$ control. In some cases, these flocculants are nonselective or work imperfectly. It is known that many highly charged planktonic algae and bacteria will adhere to certain solid surfaces if the charge or hydrophobic interaction between the organism and the solids are favorable for adhesion. The resultant microorganism-mineral entities, if formed, can flocculate and can be separated. In addition, many living organisms produce extracellular biopolymers that can also cause flocculation. The microorganism, $M$. phlei, has the properties of being both highly charged and highly hydrophobic. The aim of the present investigation is to study the effectiveness of $M$. phlei and biopolymers derived from the organism for selective flocculation and separation of fine coal from pyrite and ash.

\section{EXPERIMENTAL PROCEDURES}

\section{Cultivation of Mycobacterium phlei}

The freeze dried culture of microorganism, $M$. phlei, was first transferred to a rehydration medium (supplied by Carolina Biological Supply Company) and incubated at $35^{\circ} \mathrm{C}$ for 48 hours. $M$. phlei was grown in a culture medium consisting of the following : $10 \mathrm{~g} / 1 \mathrm{D}-(+)$-glucose, $1 \mathrm{~g} / 1$ beef extract, $1 \mathrm{~g} / \mathrm{l}$ yeast extract, and $2 \mathrm{~g} / 1$ enzymatic hydrolysate casein. The above materials were supplied by Sigma Chemical Company, St. Louis, MO. The culture medium was sterilized at $121^{\circ} \mathrm{C}$ for 25 minutes in a Spectroline Model 750 autoclave. The sterilized culture medium was cooled and the incubated bacteria was inoculated into the medium. Culturing was carried out in $250 \mathrm{ml}$ flasks continuously shaken at $150 \mathrm{rpm}$ at $35^{\circ} \mathrm{C}$ in a G24 Environmental incubator shaker (New Brunswick Scientific Co. Inc., NJ). After about 30 hours of culturing, M. phlei suspension was filtered using a $0.45 \mathrm{~mm}$ Millipore filter paper, washed twice and then resuspended in distilled water. Sterilized 
glassware and distilled water were used throughout the investigation.

\section{Sedimentation and Flocculation Experiments}

Sedimentation and flocculation tests were performed in a 11.5" tall graduated cylinder with a volume of $500 \mathrm{ml}$. A $2 \%$ solids slurry consisting of minus 325 mesh size particles was conditioned and $\mathrm{pH}$ adjusted. After $\mathrm{pH}$ adjustment, flocculant was added slowly and the suspension was stirred using a Phipps and Bird paddle stirrer at $250 \mathrm{rpm}$ for 1 minute. Further conditioning was done for 2 minutes at $50 \mathrm{rpm}$ to allow for initial floc growth to take place. Then the suspension was transferred to the graduated cylinder. Samples were taken from the bottom outlet after predetermined time intervals. The suspensions were filtered, dried and weighed.

For the sedimentation tests, the amount of material settling through the top 10" of the cylinder was used as the criteria for determining settling rates. The results of flocculation tests are reported here in terms of flocculation efficiency $\left(E_{f}\right)$ which is defined as :

$$
E_{f}=\frac{\left(W_{s o}-W_{s f}\right)}{W_{s o}}
$$

where $W_{s o}$ represents the weight of the solids in a given volume of the suspension before the addition of flocculant and $W_{s f}$ represents the same after addition of flocculant. When $W_{s o}=W_{s f}$ no flocculation occurs and $E_{f}=0$. When $W_{s f}=0, E_{f}=1$, indicating that the flocculant is effective. $E_{f}$ can be negative, in which case the flocculant acts as a dispersant.

\section{Floc Separation}

Floc separation studies were performed using a laboratory scale column flotation cell. The setup consisted of a column with a working volume of $320 \mathrm{ml}$. Nitrogen gas was passed at the bottom at the required flow rate. Flow rate of gas was controlled using a Gilmont No.13 flow meter. After flocculation, the entire slurry was transferred to the flotation cell. No $\mathrm{pH}$ adjustments were 
done at this stage. Required amount of frother (MIBC) was added and flotation was carried out for 5 minutes at the required flow rate. The float and tail were filtered, dried, weighed and analyzed.

Baseline flotation experiments were performed with coal using kerosene as collector and MIBC as frother. In this case, $\mathrm{pH}$ adjustments were carried out before the addition of frother and promoter. After 4 minutes of conditioning, the coal slurry was transferred to the column and flotation was carried out for 5 minutes. These experiments were performed for comparison with the floc flotation results.

\section{RESULTS AND DISCUSSION}

\section{Sedimentation and Flocculation Experiments}

In the last quarterly report, we had reported the effect of whole cells of $M$. phle $i$ on the flocculation efficiency of IL No.6 coal. During this quarter, the effect of $M$. phlei on the flocculation of KY No.9 coal was investigated. Also, the flocculation characteristics of IL No.6 and KY No.9 coals in the presence of ruptured cells of $M$. phlei was studied as a function of $\mathrm{pH}$, concentration and time.

The effect of ruptured cells on the amount of IL No.6 coal settled as a function of time is shown in Figure 1. As seen, with ruptured cells, the maximum amount coal settled is only about $60 \%$ after 3 minutes at a cell concentration of $300 \mathrm{ppm}$ and $\mathrm{pH}$ of 6.5 . The flocculating ability of ruptured cells of $M$. phlei is inferior when compared to the whole cells and this can be attributed to the loss of extracellular surfactants during sonication. The bacterial cell concentration and $\mathrm{pH}$ were selected from the contact angle measurements in the presence of ruptured cells. Figure 2 shows the effect of concentration on the flocculation efficiency for IL No.6 coal. It can be seen that in case of ruptured cells, the $E_{f}$ increases as the concentration is increased and a maximum value of about 0.7 is reached only at concentrations above $300 \mathrm{ppm}$. Even though the extracellular surfactants have been removed during sonication, the bacterial cell wall may still contain some proteins and lipids 
which can cause adherence to coal surface and hence flocculation. Because there might be very small amounts of proteins or lipids left in the cell wall, the concentration of ruptured cells (when compared with whole cells) required for flocculation is very high ( $>300 \mathrm{ppm})$. The effect of $\mathrm{pH}$ on the flocculation efficiency of IL coal with ruptured cell is shown in Figure 3. In the absence of bacteria, the $E_{f}$ is about 0.11 and does not change with $\mathrm{pH}$. However, with ruptured cells, the $E_{f}$ changes and is strongly dependent on $\mathrm{pH}$. A clear maxima is observed in the neutral $\mathrm{pH}$ range which is close to the isoelectric point of the ruptured cells. However, as mentioned in the last report, the maximum $E_{f}$ with whole cells is in the $\mathrm{pH}$ range of 3.5-4.5. At high ruputured cell concentrations of $300 \mathrm{ppm}$ the maximum efficiency achieved is about 0.61 which is much lower compared to the results obtained with whole cells.

The effect of different flocculants on the flocculating behavior of KY No.9 coal was investigated. The amount of coal settled as a function of time is shown in Figure 4. With M. phlei whole cells, the maximum amount of coal settled is about $80 \%$ after 4 minutes. In the presence of conventional polymeric flocculants, the maximum amount settled is about $75-77 \%$. However, with ruptured cells of $M$. phlei the maximum amount of $\mathrm{KY}$ coal settled was about $58 \%$. The decrease in the amount of coal settled with ruptured cells is similar to IL coal and can be explained similarly. The effect of concentration of different flocculants on flocculation efficiency is shown in Figure 5. In the presence of whole cells, a maximum $E_{f}$ of about 0.8 is obtained at concentrations greater than $200 \mathrm{ppm}$ and remains constant at higher concentrations. On the other hand, with ruptured cells $E_{f}$ increases with increasing concentration and a maximum $E_{f}$ of 0.57 is observed at concentrations greater than $300 \mathrm{ppm}$. However, with PEO and PAM, $E_{f}$ increases with increase in concentration but decreases at concentrations greater than $200 \mathrm{ppm}$ which can be attributed due to stearic stabilization. This again demonstrates that the flocculation of coal with $M$. phlei is through hydrophobic interactions.

The effect of $\mathrm{pH}$ on the $E_{f}$ of KY No.9 coal with whole cells is shown in Figure 6. The flocculation efficiency increases with increasing concentration and a maximum is observed at $\mathrm{pH}$ 4. This behavior is very similar to IL No.6 coal. However, the maximum $E_{f}$ obtained was only about 
0.78 while with IL No.6 coal the maximum obtained was 0.95 . This difference might be due to the difference in surface hydrophobicities of both coals. IL No.6 coal is more hydrophobic compared to KY No.9 coal and this probably leads to higher flocculation efficiencies. At concentrations greater than $200 \mathrm{ppm}$, no further increase in $E_{f}$ was observed. Similar tests were carried out with ruptured cells and the results are shown in Figure 7. A maximum $E_{f}$ is observed in the slightly acidic to neutral $\mathrm{pH}$ range.

\section{Floc Separation}

After flocculation, the flocs were transferred to the column flotation cell. No $\mathrm{pH}$ adjustments were done and only MIBC as frother $(0.7 \mathrm{~kg} /$ ton $)$ was added. Nitrogen gas was used for flotation and an optimum flowrate of $0.6 \mathrm{~L} / \mathrm{min}$ was maintained. Flotation was carried out for 5 minutes. For comparison purposes, the effect of kerosene and frother on the floatability of coal was evaluated at selected $\mathrm{pH}$ values. The flotation results for IL No.6 coal at $\mathrm{pH} 3.6$ with different reagents is shown in Table 1 below.

Table 1. Flotation results of IL No.6 Coal at pH 3.6 (Gas flowrate $0.6 \mathrm{l} / \mathrm{min}$ and frother dosage $0.7 \mathrm{~kg} / \mathrm{ton}$ )

\begin{tabular}{|l|c|c|c|}
\hline & $\begin{array}{c}\text { Combustible } \\
\text { Recovery (\%) }\end{array}$ & $\begin{array}{c}\text { Pyritic Sulfur } \\
\text { Rejection (\%) }\end{array}$ & $\begin{array}{c}\text { Ash Rejection } \\
(\%)\end{array}$ \\
\hline Frother Only & 50 & 45 & 44 \\
\hline Frother + Kerosene & 76 & 56 & 46 \\
\hline Frother + Whole Cells & 82 & 68 & 48 \\
\hline Frother + Ruptured Cells & 60 & 50 & 45 \\
\hline Frother + PEO & 28 & 35 & 40 \\
\hline Frother + PAM & 25 & 33 & 42 \\
\hline
\end{tabular}

With frother alone, the combustible recovery of coal is about $50 \%$ and the pyritic sulfur 
rejection is $45 \%$. In the presence of an oily promoter like kerosene, the combustible recovery and pyritic sulfur rejected increased substantially to $76 \%$ and $56 \%$ respectively. When coal flocculated with whole cells of $M$. phlei was floated, the amount of combustibles increased to $82 \%$ while the pyritic sulfur rejection increased to $68 \%$. Adhesion of $M$. phlei increases the surface hydrophobicity of coal which probably enhances the floatability of coal. Although the combustible recovery increased by only $6 \%$ when compared with kerosene, the pyritic sulfur rejection increased by $12 \%$. This meant that the flocculation of coal with $M$. phlei followed by flotation produced a higher quality product than flotation with kerosene alone. It should however be noted that $\mathrm{pH}$ and flotation time also can influence flotation of coal. The effect of $\mathrm{pH}$ and time on the floatability of coal are presently being evaluated.

When coal flocculated with ruptured cells of $M$. phlei was floated, only $60 \%$ of the combustibles were recovered along with a sulfur rejection of $50 \%$ which is due to the decreased hydrophobicity of $M$. phlei cells after sonication. However, when flotation was carried out after flocculation with synthetic flocculants such as PEO and PAM, the combustible recovery was only about $25-28 \%$ with a sulfur rejection of $33-35 \%$. This is because of the hydrophilic nature of synthetic polymeric flocculants. Similar studies were conducted with KY No.9 coal which is less hydrophobic compared to IL No.6 coal and the results are shown in Table 2 below.

Table 2. Flotation results of KY No.9 coal at $\mathrm{pH} 3.9$ (Gas flowrate $0.6 \mathrm{l} / \mathrm{min}$ and frother dosage $0.7 \mathrm{~kg} / \mathrm{ton}$ )

\begin{tabular}{|l|c|c|c|}
\hline & $\begin{array}{c}\text { Combustible } \\
\text { Recovery (\%) }\end{array}$ & $\begin{array}{c}\text { Pyritic Sulfur } \\
\text { Rejection (\%) }\end{array}$ & $\begin{array}{c}\text { Ash Rejection } \\
(\%)\end{array}$ \\
\hline Frother Only & 45 & 38 & 42 \\
\hline Frother + Kerosene & 60 & 50 & 44 \\
\hline Frother + Whole Cells & 70 & 63 & 55 \\
\hline Frother + Ruptured Cells & 48 & 40 & 40 \\
\hline Frother + PEO & 20 & 30 & 35 \\
\hline Frother + PAM & 18 & 31 & 38 \\
\hline
\end{tabular}


As can be seen, the flotation results are very similar to those of IL No.6 coal in the presence of various flocculants and kerosene. The best results were obtained through flocculation followed by flotation with $M$. phlei whole cells. However, the combustible recovery is lower compared to that of IL No.6 coal. This might be due to KY No.9 coal being less hydrophobic compared to IL No.6 coal. These tests clearly indicate that $M$. phlei not only acts as an effective flocculant, but also acts as a good flotation collector for coal.

\section{DLVO Calculations}

In order to obtain a better picture of the interaction between coal $/$ mineral and $M . p h l e i$, the interaction potential energy between these suspended particles was considered next. The theoretical analysis of the interactions between colloidal particles was originally developed by Derjaguin and Landau (1941) and Verwey and Overbeek (1946) in terms of repulsive and attractive potential energies of interaction (more commonly known as the DLVO theory).

The total interaction energy is calculated using the following equation :

$$
V_{T}=V_{R}+V_{A}
$$

where,

$V_{R}=$ repulsive potential energy due to formation of electrical double layer around particles and $V_{A}=$ van der Waals attractive potential energy

The electrostatic repulsive force between mineral and M. phlei particles can be expressed by the following equation :

$$
V_{R}=\frac{\left(\epsilon a_{1} a_{2}\right)}{4\left(a_{1}+a_{2}\right)}\left(\Psi_{1}^{2}+\psi_{2}^{2}\right)\left[\frac{2 \Psi_{1} \Psi_{2}}{\left(\psi_{1}^{2}+\Psi_{2}^{2}\right)} \ln \frac{\left(1+\exp \left(-\kappa H_{0}\right)\right.}{\left(1-\exp \left(-\kappa H_{0}\right)\right.}+\ln \left(1-\exp \left(-2 \kappa H_{0}\right)\right)\right]
$$

where

$\epsilon$ is the dielectric constant of the aqueous medium $=8.84 \times 10^{-10} \mathrm{ergs} / \mathrm{mV}^{2} . \mathrm{cm}$ 
$a_{1}$ is the diameter of coal $/$ mineral particle $=10 \mu \mathrm{m}-15 \mu \mathrm{m}$

$a_{2}$ is the diameter of M. phlei $=1 \mu \mathrm{m}$

$\Psi_{1}$ and $\Psi_{2}$ are surface potentials of coal/mineral and $M$. phlei respectively

$H_{0}$ is the minimum separation distance between particle and $M$. phlei surface

Assuming $a_{1} \gg>a_{2}, a_{1} a_{2} /\left(a_{1}+a_{2}\right)$ can be changed to $a_{2}$ and Equation 3 can be reduced to

$$
V_{R}=\frac{\epsilon a_{2}}{4}\left(\Psi_{1}^{2}+\psi_{2}^{2}\right)\left[\frac{2 \Psi_{1} \Psi_{2}}{\left(\Psi_{1}^{2}+\Psi_{2}^{2}\right)} \ln \frac{\left(1+\exp \left(-\kappa H_{0}\right)\right)}{\left(1-\exp \left(-\kappa H_{0}\right)\right)}\right]+\ln \left(1-\exp \left(-2 \kappa H_{0}\right)\right)
$$

The London - van der Waals attractive force $V_{A}$ is given by :

$$
V_{A}=-\frac{\left(a_{1} a_{2}\right) A}{6\left(a_{1}+a_{2}\right) H_{0}}
$$

Considering the diameter of coal/mineral particle to be much greater than that of $M$. phlei, Equation 5 is simplified to :

$$
V_{A}=-\frac{a_{2} A}{6 H_{0}}
$$

The most important parameters determining the van der Waals interaction are the Hamaker constant $(A)$, which is a material property, the distance $\left(H_{0}\right)$ between the bacterium and coal $/$ mineral, and the geometry of the particles.

The Hamaker constant, $A_{3 / 2}$, for coal/mineral-water-M. phlei system was evaluated using the following approximations. 


$$
\begin{gathered}
A_{12}=\left[\sqrt{A_{11}}-\sqrt{A_{22}}\right]^{2} \\
A_{13}=\left[\sqrt{A_{11}}-\sqrt{A_{33}}\right]^{2} \\
A_{23}=\left[\sqrt{A_{22}}-\sqrt{A_{33}}\right]^{2} \\
A_{312}=A_{32}+A_{11}-A_{31}-A_{21}
\end{gathered}
$$

where 1 represents water, 2 represents $M$. phlei and 3 represents the mineral. The Hamaker constant for water $\left(A_{11}\right)$ was selected from Viser $(1972)$ as $4.38 \times 10^{-13}$ ergs. The Hamaker constant for $M$. phlei has been estimated using the Fowkes equation (1967) as given below.

$$
A_{22}=6 \pi r_{11}^{2} \gamma_{s}^{d}
$$

where $r_{l l}$ represents the intermolecular distance and $\psi_{s}{ }^{d}$ the dispersion component of surface free energy of a solid. According to Fowkes, for water and systems with volume elements such as oxide ions, metal atoms, $\mathrm{CH}_{2}$ and $\mathrm{CH}$ groups which have nearly the same size, the value of $6 \pi \mathrm{r}_{11}{ }^{2}=1.44$ x $10^{-14}$ can be used. The $\psi_{s}$ value for $M$. phlei has been estimated by Chen (1992) to be 43.6 dyne $/ \mathrm{cm}$. Using these values, the Hamaker constant for $M$. phle $i$ was estimated to be about $6.26 \times 10^{-13}$ ergs. The value for $6 \pi r_{11}^{2}$ can be assumed to be valid even in the case of ruptured cells since the cell wall is made up of mainly lipids and proteins and contains $\mathrm{CH}_{2}$ and $\mathrm{CH}$ groups. However, since the contact angle of ruptured cells was about $43^{\circ}$, the $\gamma_{\mathrm{s}}{ }^{\mathrm{d}}$ value was estimated to be $62.5 \mathrm{dyne} / \mathrm{cm}$, and the Hamaker constant for ruptured cells was found to be $9 \times 10^{-13}$ ergs.

The values of $\gamma_{s}{ }^{d}$ for coal and coal-pyrite were taken from Good et al. (1990) and Raichur (1992). It has been very well established that the value of $\gamma_{s}{ }^{d}$ for coal is independent of coal rank. Therefore, the same value has been used for both coal samples. The value for quartz was taken from 
Fowkes (1967). Based on these values the following values of $A_{33}$ were determined and are shown in Table 3.

Table 3. The $\gamma_{s}{ }^{d}$ values and Hamaker constants $\left(A_{33}\right)$ for different minerals

\begin{tabular}{|l|c|c|}
\hline \multicolumn{1}{|c|}{ Mineral } & $\gamma_{\mathrm{s}}{ }^{\mathrm{d}}($ dyne $/ \mathrm{cm})$ & $A_{33}$ (ergs) \\
\hline IL No.6 Coal & 36 & $5.18 \times 10^{-13}$ \\
\hline KY No.9 Coal & 36 & $5.18 \times 10^{-13}$ \\
\hline Coal pyrite & 58.5 & $8.35 \times 10^{-13}$ \\
\hline Quartz & 123 & $1.77 \times 10^{-13}$ \\
\hline
\end{tabular}

For the above calculations, the separation distance, $H_{0}$ was varied from 1 to $100 \AA$ and the various surface potentials at different $\mathrm{pH}$ values are listed below in Table 4.

Table 4. Zeta potential values of different samples (in $\mathrm{mV}$ ) used for DLVO calculations

\begin{tabular}{|c|c|c|c|c|c|c|c|}
\hline $\mathrm{pH}$ & $\begin{array}{c}\text { Whole } \\
\text { Cells }\end{array}$ & $\begin{array}{c}\text { Ruptured } \\
\text { Cells }\end{array}$ & $\begin{array}{c}\text { IL No.6 } \\
\text { Coal }\end{array}$ & $\begin{array}{c}\text { KY No.9 } \\
\text { Coal }\end{array}$ & ICPY & MPY & Quartz \\
\hline 2 & -2 & 28 & 28 & 16 & 31 & 25 & -6 \\
3 & -8 & 23 & 23 & 13 & 24 & 20 & -20 \\
4 & -16 & 19 & 17 & 10 & 20 & 20 & -26 \\
6 & -28 & 12 & -4 & -7 & 1 & 17 & -33 \\
8 & -38 & -13 & -22 & -21 & -21 & -6 & -36 \\
10 & -46 & -17 & -34 & -31 & -28 & -17 & -39 \\
\hline
\end{tabular}

Values of zeta potential were used in place of surface potentials for the total interaction energy calculations. The use of zeta potential in place of surface potentials is justified if it is considered that the plane of shear approximately coincides with the stern plane and that this layer is tightly bound 
to, and may be considered a part of, the surface.

The value of $k$ was calculated using the well known expression

$$
\frac{1}{k}=\frac{4.3}{\sqrt{2 I}} \AA
$$

where $I$ is the ionic strength of the solution. This equation is valid when water is used as solvent at $25^{\circ} \mathrm{C}$. The ionic strength was calculated using the equation

$$
I=\frac{1}{2} \sum\left[C_{i} Z_{i}^{2}\right]
$$

where $C_{i}$ is the concentration of ionic species and $Z_{i}$ is the charge of the ionic species. In this case $0.01 \mathrm{M} \mathrm{NaNO}_{3}$ was used as electrolyte. Using this value, the value of $I$ and then the value of $k$ were calculated and found to be 0.1 and $0.03289 / \AA ̊ \AA$ respectively.

The total interaction energy was calculated as a function of separation distance $H_{0}$ and as a function of $\mathrm{pH}$. The separation distance was varied from 1 to $100 \AA$ while the $\mathrm{pH}$ was varied from 2 to 10 . The interaction energy for between mineral particles/whole cells and mineral particles/ruptured cells was calculated.

The total interaction energy for IL No.6 coal as a function of separation distance is shown in Figure 8. As can be seen with an increase in separation distance, the interaction energy becomes less negative and approaches zero at distances greater than $40 \AA$. Also, as the pH increases, the interaction energy becomes positive which means that repulsion becomes predominant. A similar behavior was observed with other minerals. Figure 9 shows the effect of $\mathrm{pH}$ on the total interaction energy for IL No. 6 coal. As pH is increased, the total interaction energy becomes more negative up to $\mathrm{pH} 4$. Above $\mathrm{pH} \mathrm{4}$, the interaction energy becomes less negative. At $\mathrm{pH} \mathrm{4}$, a minimum in interaction energy is observed and this corresponds to the maximum in adhesion and flocculation efficiency. Also, it is clear in Figure 9, that as $H_{0}$ increases the interaction energy increases thereby 
decreasing adhesion.

Figure 10 compares the interaction energies of all the samples with whole cells of $M$. phlei as a function of $\mathrm{pH}$. KY No.9 coal exhibited a similar trend as IL No.6 coal. However, coal-pyrite also had a minimum at $\mathrm{pH} 4$ and the interaction energies were very similar to that of coal. This means that $M$. phlei should adhere to coal-pyrite as it does to coal which is, however, not the case. One of the reasons could be that the values of zeta potential of coal-pyrite measured may not be the true values. Since the surface of coal-pyrite is covered with coal/carbonaceous matter, the zeta potentials may be of the coal particles rather than of the pyrite particles. Also, the dielectric constant of water is used for calculations, but the dielectric constant of bound water is different for that of the bulk water and is dependent on the surface property of the mineral.

Further, the interaction energy calculations for the ruptured cell/mineral interface were also calculated. Figure 11. compares the interaction energies for whole cell/coal and ruptured cell/coal interface for IL No.6 coal. It is clear that upon rupturing the surface of bacterial cell becomes less hydrophobic and more positively charged. This leads to a substantial decrease in interaction energy when compared with whole cells which in turn decreases the amount of ruptured cells adhering to coal surface. Similar results were also observed with other minerals and are shown in Figures 1214.These results demonstrate that due to increase in interaction energy, the adhesion of ruptured cells is less compared to whole cells. From the above discussion it is obvious that DLVO theory can explain the phenomena of bacterial adhesion onto coal and minerals with the exception of coalpyrite.

\section{FUTURE WORK}

Currently, the effect of $\mathrm{pH}$ and time on the flotation of coal flocs is being investigated. The interaction between bacteria and coal surface is being studied by calorimetry. The effect of different parameters such as $\mathrm{pH}$ and concentration of $M$. phlei will be investigated. 


\section{REFERENCES}

Chen, S., 1992, M. S. Thesis, University of Nevada, Reno.

Derjaguin, B. V. and Landau, L. D., 1941, "Theory of the Stability of Strongly Charged Lyophobic Sols, and of the Adhesion of Strongly Charged Particles in Solution of Electrolytes," Acta Physicochim USSR, Vol. 14, pp. 633-662.

Fowkes, F. M., 1964, “Attractive Forces at Interfaces,” Ind. Eng. Chem., Vol. 56, No. 12, pp. 40-52.

Good, R. J., Srivatsa, N. R., Islam, M., Huang, H. T. L. and Van Oss, C. J., 1990, "Theory of the acid-base hydrogen bonding interactions, contact angles, and the hysteresis of wetting: application to coal and graphite surfaces," J. Adhesion Sci. Technology, Vol. 4, No. 8, pp. 607-617.

Misra, M., Smith, R. W. and Raichur, A. M., Novel Microorganism for Selective Separation of Coal from Ash and Pyrite, Technical Progress Reports, DOE Grant No. DE-FG22-93PC93215.

Raichur, A. M., 1992, M. S. Thesis, University of Kentucky, Lexington, KY.

Verwey, E. J. W. and Overbeek, J. Th. G., 1946, "Long Distance Forces Acting Between Colloidal Particles," Trans. Faraday Soc., 42B, pp. 117-123.

Viser, J., 1972, "On Hamaker Constants; a Comparison Between Hamaker Constants and Lifshitzvan der Waals Constants," Adv. Colloid and Int. Sc., Vol.3, pp. 331-363. 


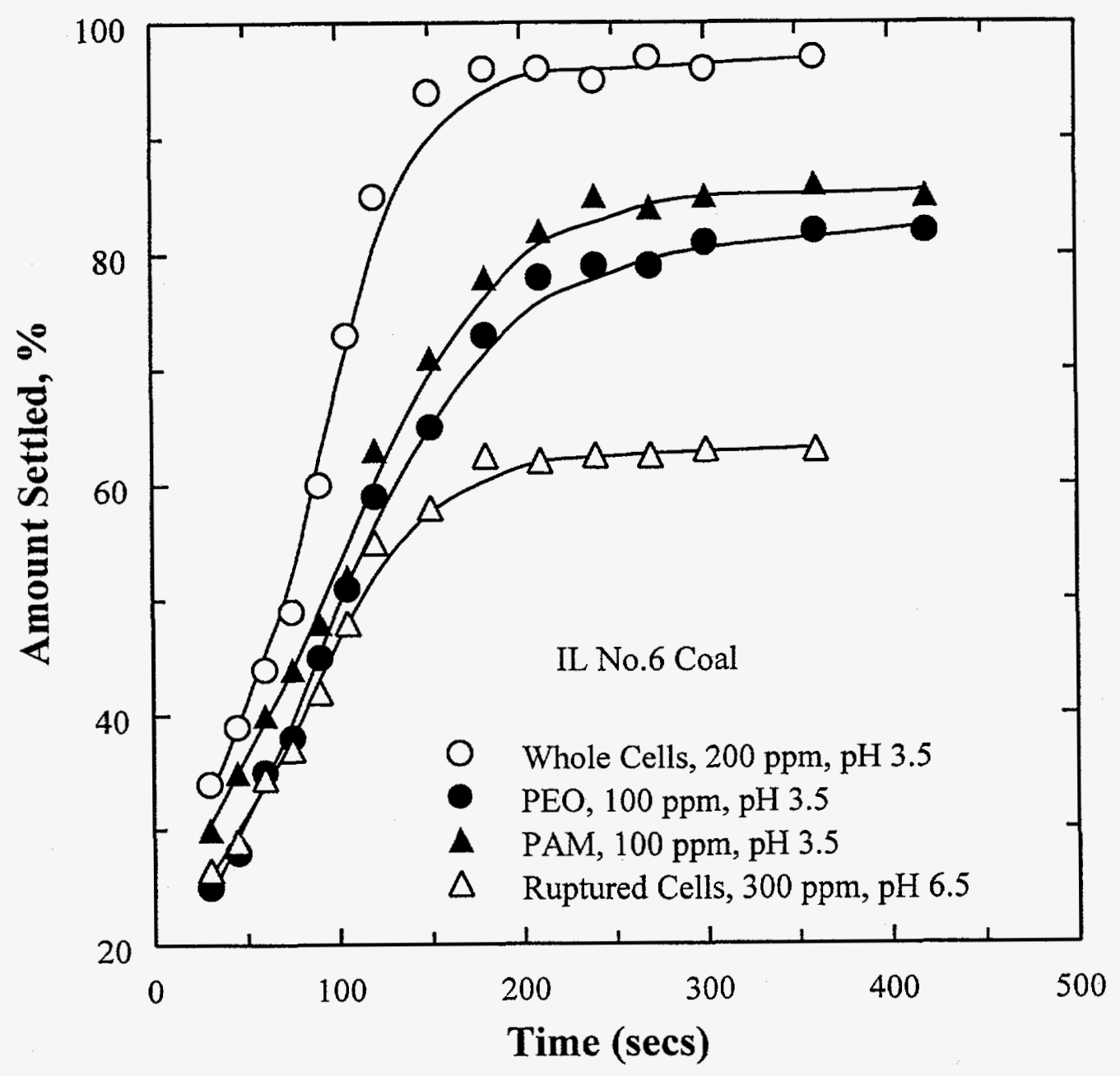

Figure 1. Amount of coal settled as a function of time in the presence of different flocculants 


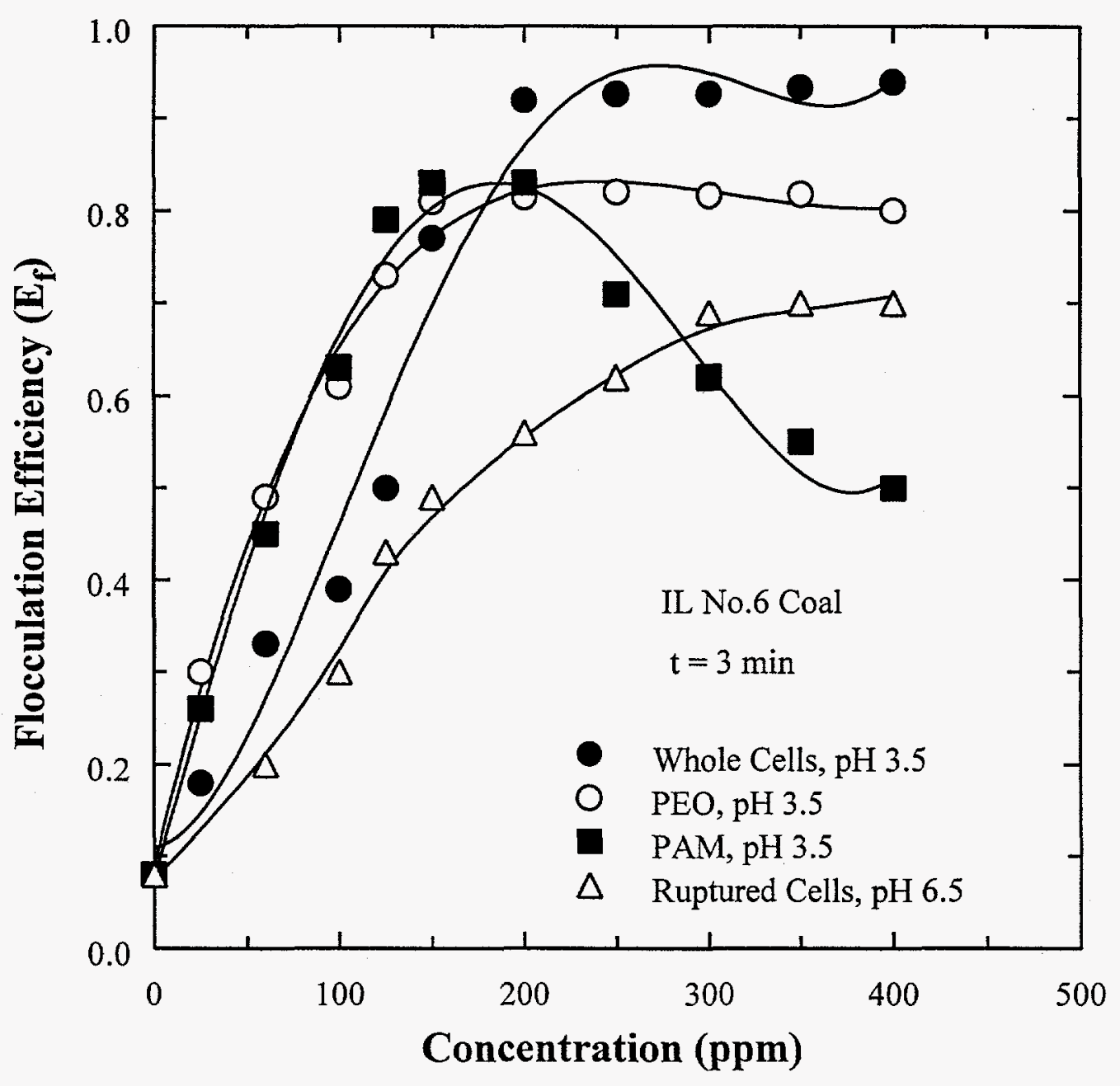

Figure 2. The effect of concentration of different flocculants on the flocculation efficiency of IL No.6 coal 


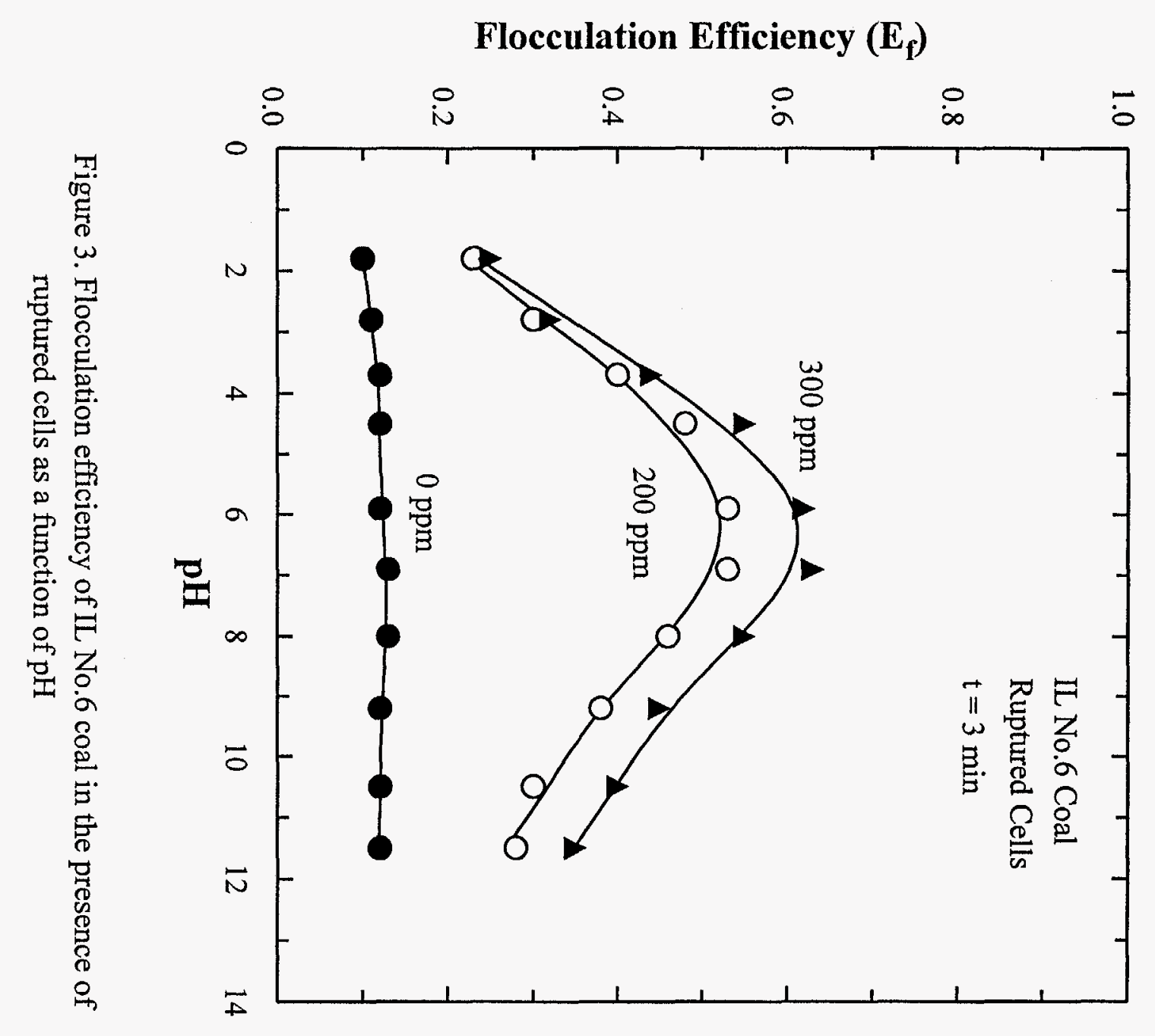




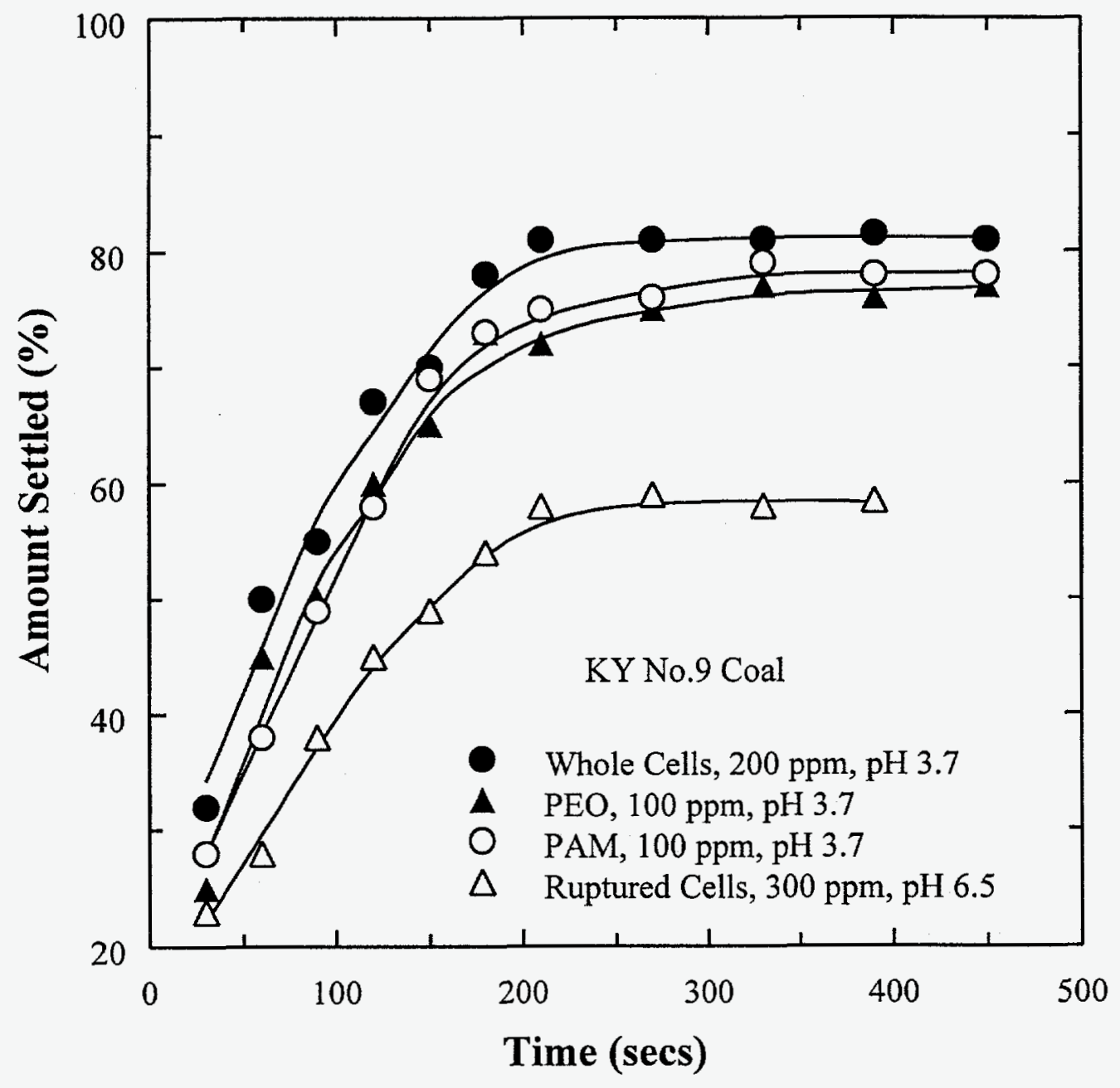

Figure 4. Amount of KY No.9 coal settled as a function of time in the presence of different flocculants 


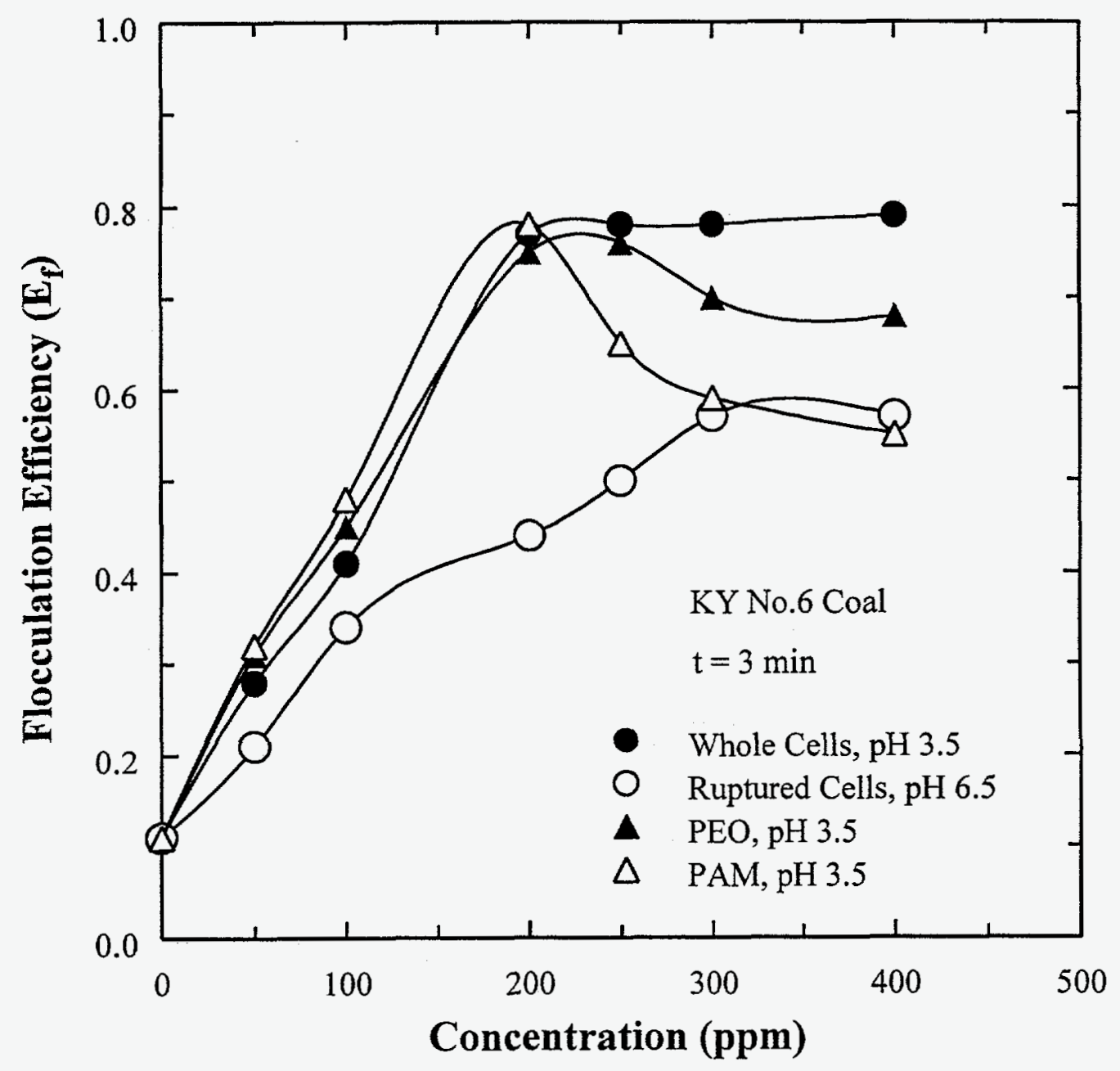

Figure 5. The effect of concentration of different flocculants on the flocculation efficiency of KY No.9 coal 


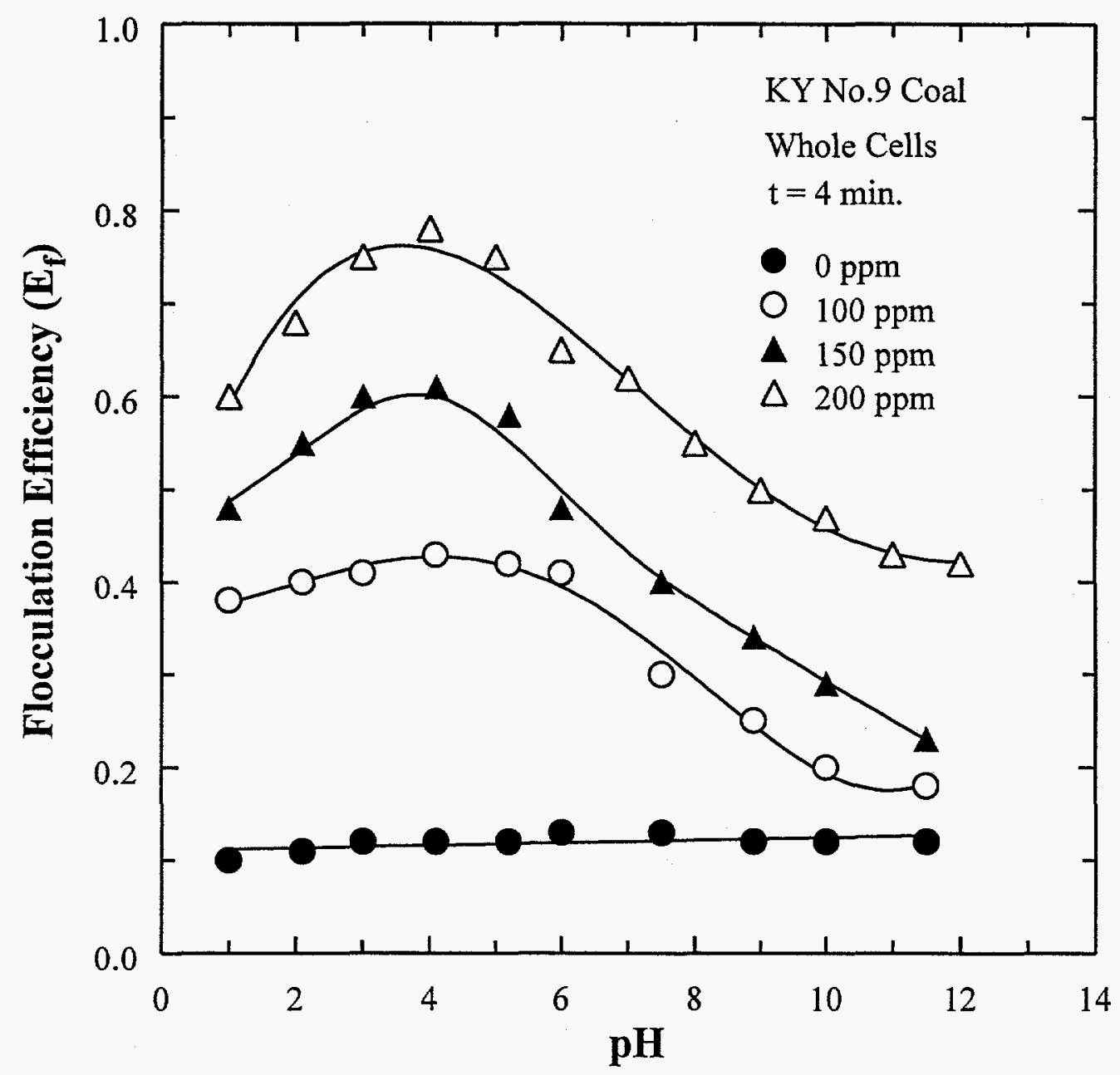

Figure 6. Effect of $\mathrm{pH}$ on the flocculation efficiency of KY No.9 coal in the presence of whole cells of M. phlei 


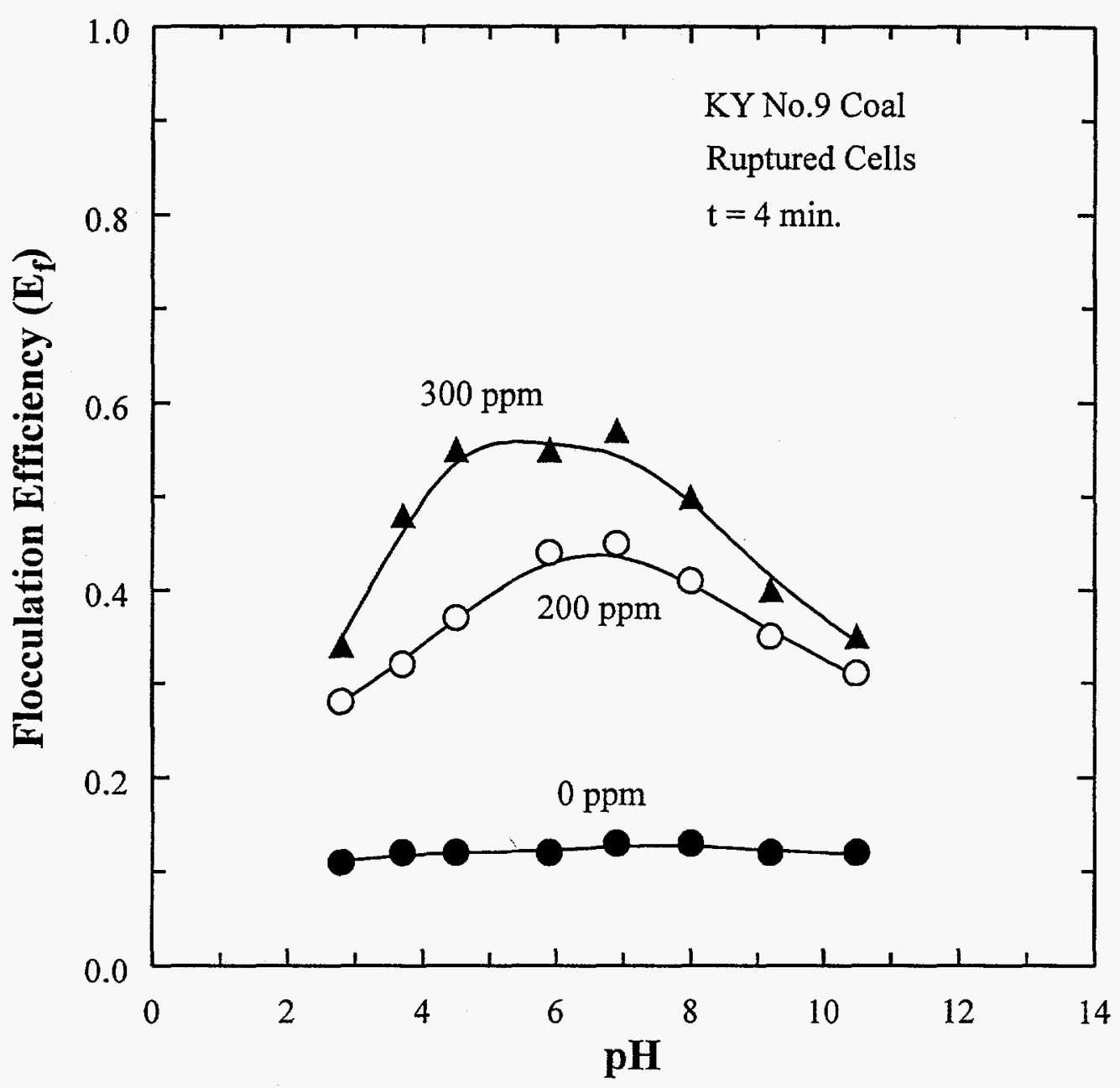

Figure 7. Effect of $\mathrm{pH}$ on the flocculation efficiency of KY No.9 coal in the presence of ruptured cells of $M$. phlei 


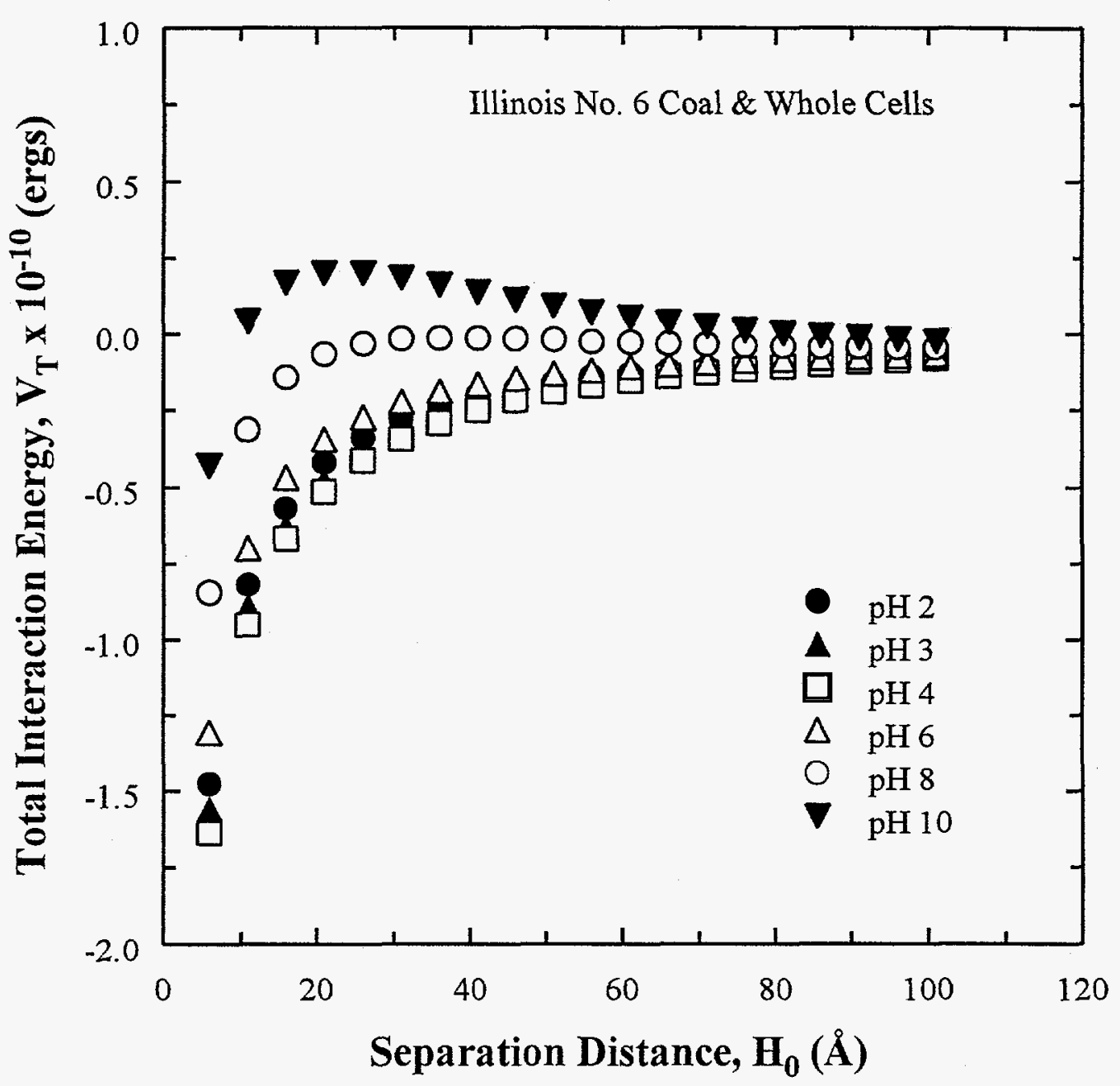

Figure 8. The variation of total interaction energy as a function of separation distance at different $\mathrm{pH}$ values for IL No.6 coal and whole cells of $M$. phlei 


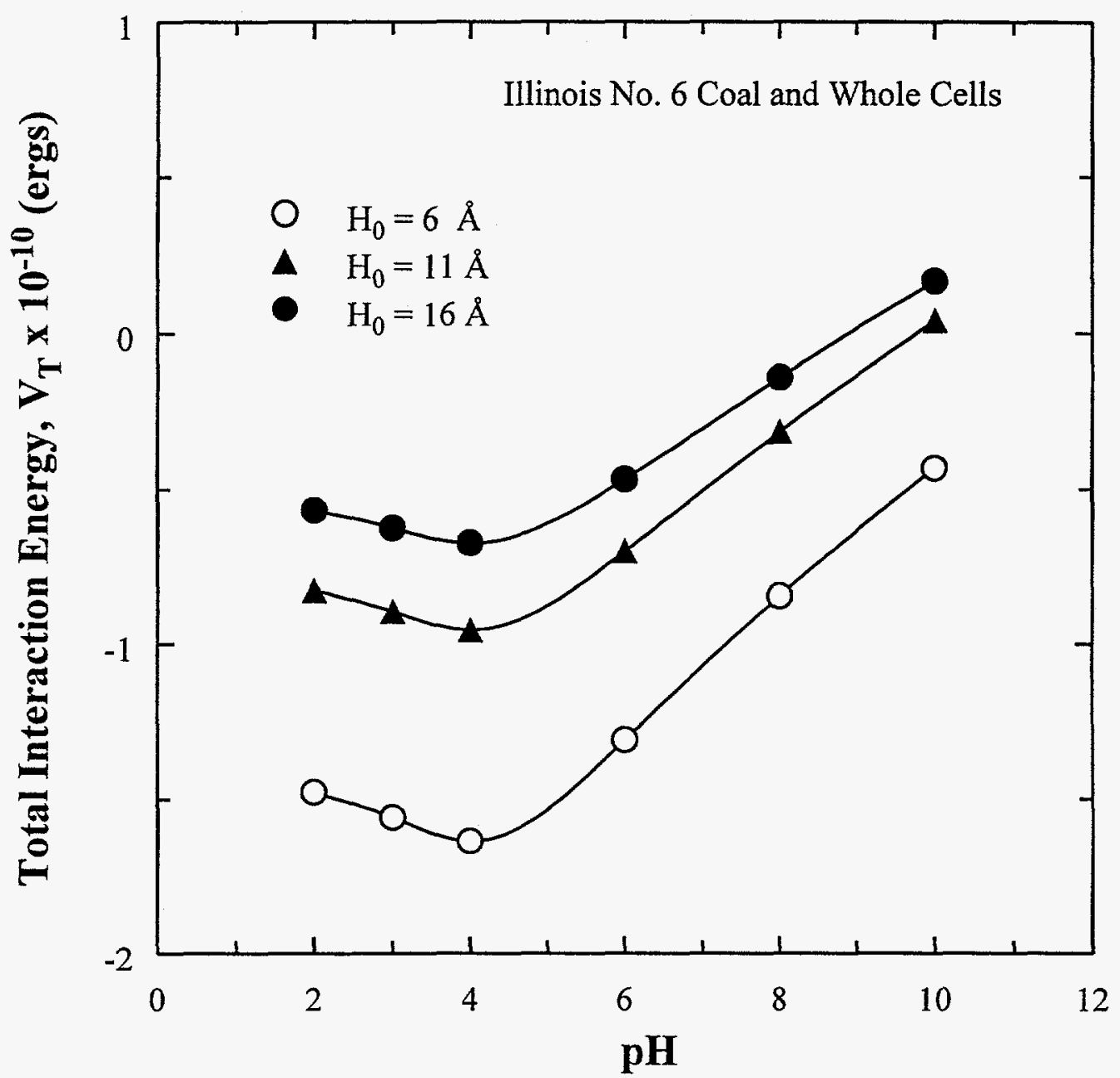

Figure 9. Effect of $\mathrm{pH}$ on the total interaction energy for IL No.6 coal and whole cells of $M$. phlei 


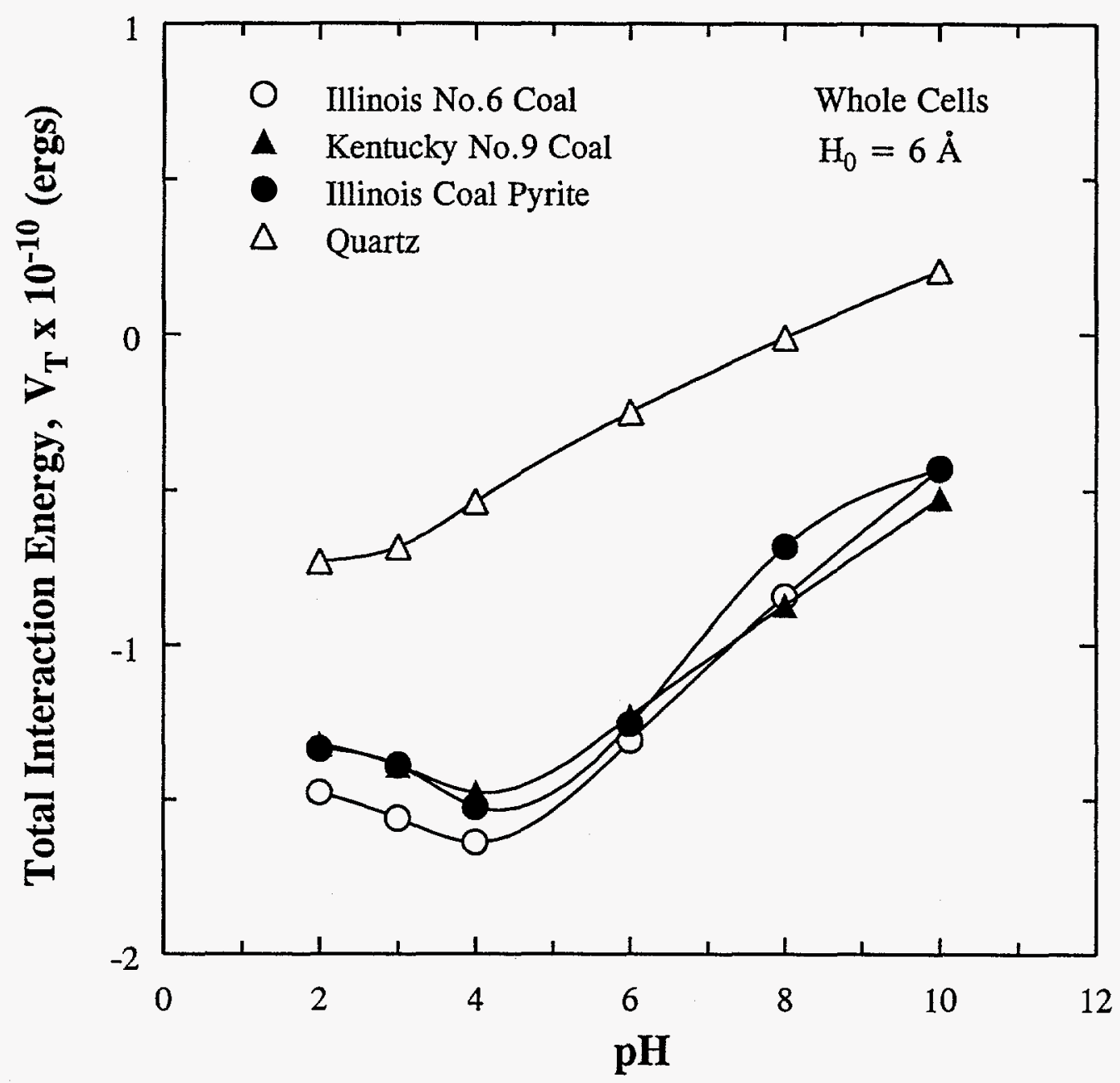

Figure 10. Comparison of total interaction energies for coal, coal-pyrite and quartz with whole cells of $M$. phlei as a function of $\mathrm{pH}$ 


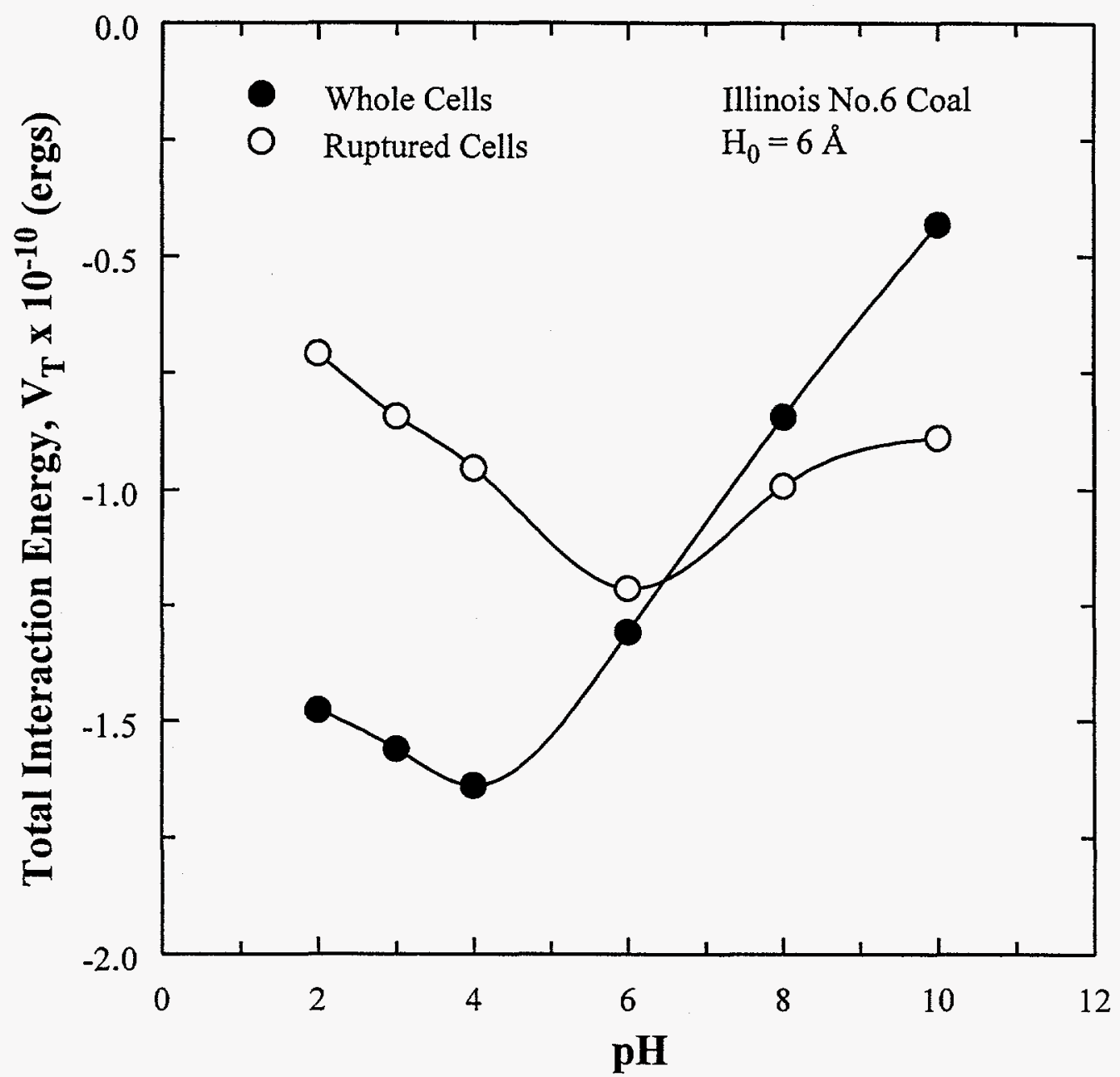

Figure 11. Comparison of interaction energies for whole cell/coal and ruptured cells/coal interface for IL No.6 coal 


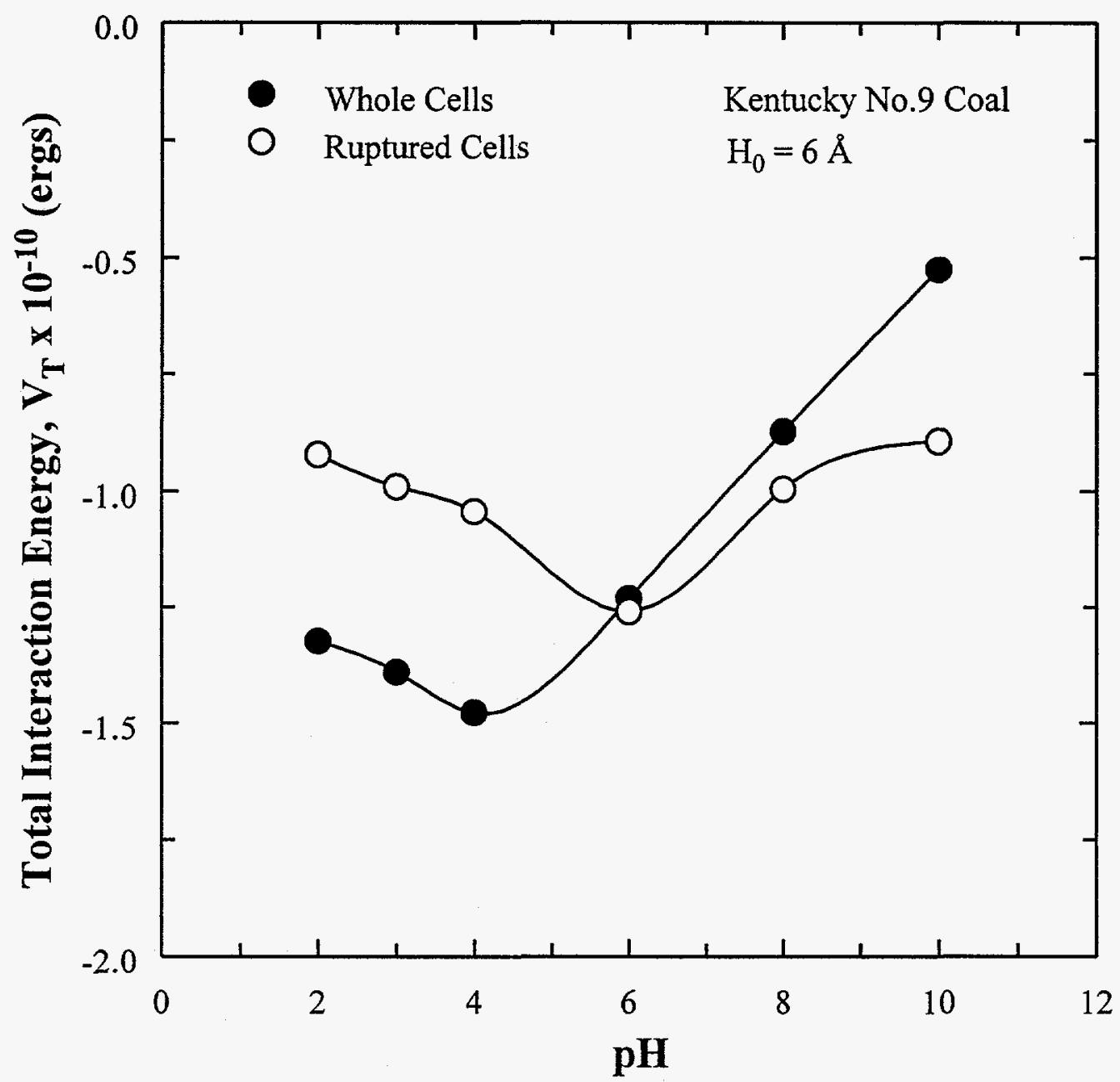

Figure 12. Comparison of interaction energies for whole cells/coal and ruptured cells/coal interface for KY No.9 coal 


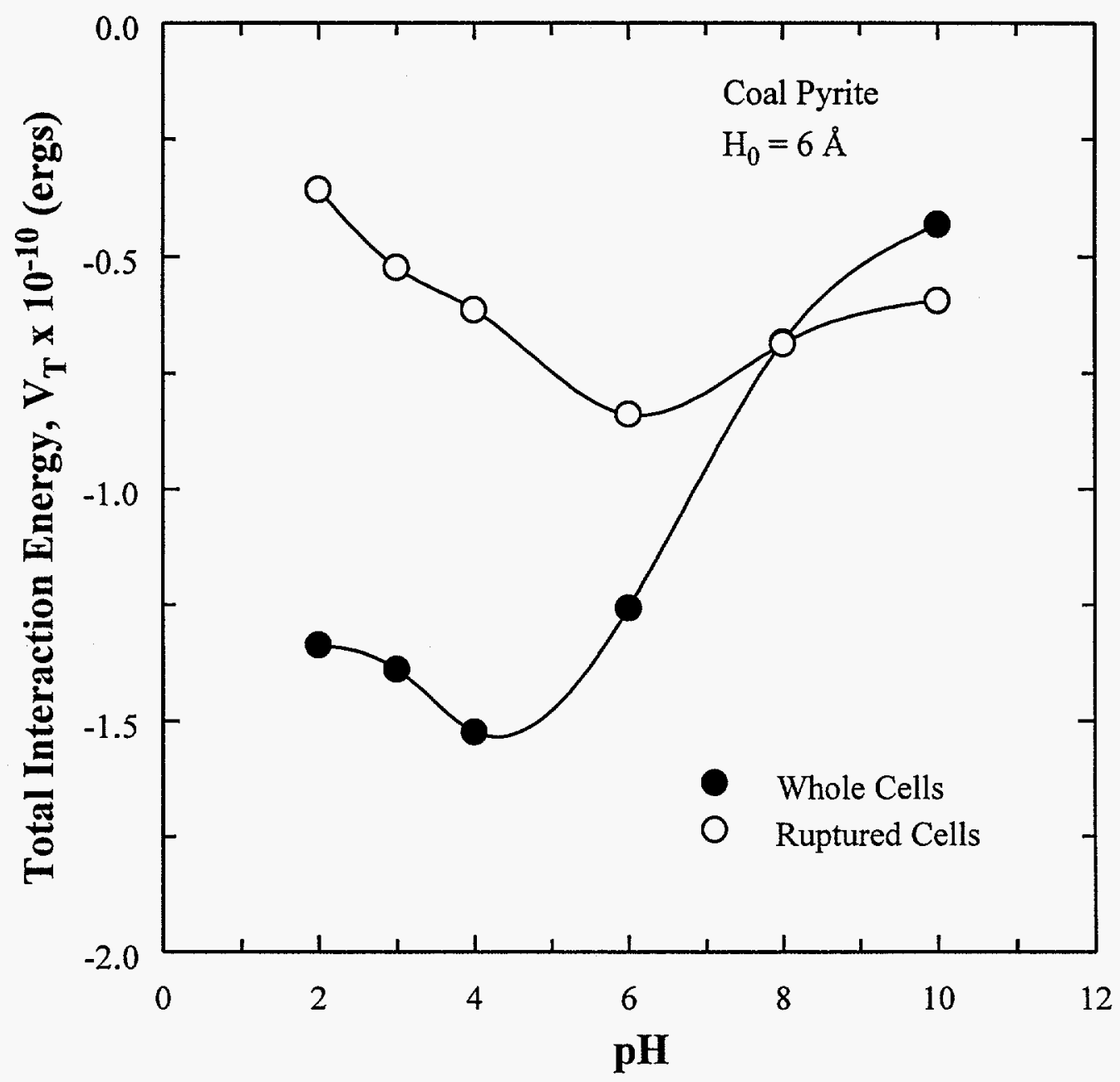

Figure 13. Comparison of interaction energies for whole cell/coal-pyrite and ruptured cells/coal-pyrite interface 


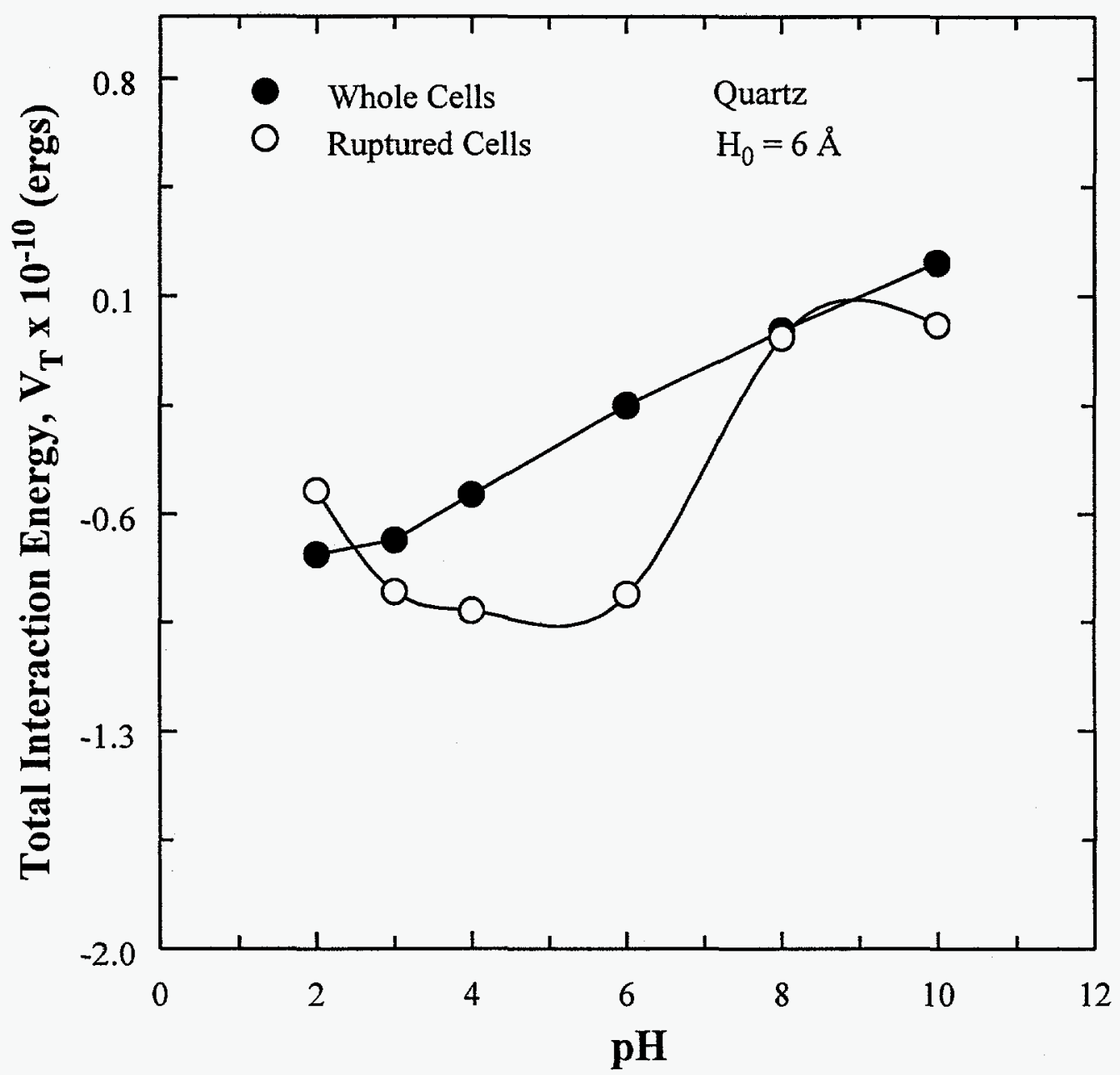

Figure 14. Comparison of interaction energies for whole cells/quartz and ruptured cells/quartz interface 